\title{
Chronic pain map in the Internet: exploratory study
}

\author{
O mapa da dor crônica na internet: um estudo exploratório
}

\author{
Alessandra Spedo Focosi ${ }^{1}$, Rosane Mantilla de Souza ${ }^{1}$
}

DOI 10.5935/1806-0013.20160024

\section{ABSTRACT}

BACKGROUND AND OBJECTIVES: Access to the Internet is progressively growing and it is considered major information source, even about health. The number of chronic pain patients is increasing and the access to specialized assistance is still scarce. The web has the possibility of involving a large number of people, but there are still few studies exploring the relationship between pain and Internet. So, this study aimed at characterizing the universe faced by Brazilians when searching about pain in the Internet.

METHODS: The study consisted of a documental analysis of the first Google web query page using eight keywords selected considering bibliographic references, Google Trends tool and different means of expression of the population ("pain", "chronic pain"; "I have pain"; "I feel pain"; "headache"; "back pain"; and "low back pain").

RESULTS: The search has resulted in 64 valid results, classified in websites and Virtual Settlement. Among websites, the following pages were found: health portals (19); developed by specialists or medical societies (14); online newspapers and journals (19); and virtual libraries (2). In the Virtual Settlement category most prevalent were blogs (1), forums (3), Facebook pages (1), You Tube videos (1) and Wikipedia pages (4). There were also portals allowing interaction between users and webmasters.

CONCLUSION: Internet has plenty of information about pain, which calls the attention to the importance of health professionals using the Internet as a partner to promote their patients' health and to teach them how to cope with its disadvantages.

Keywords: Chronic pain, Empowerment, Internet.

1. Pontifícia Universidade Católica de São Paulo, Departamento de Psicologia Clínica, Sấo Paulo, SP, Brasil.

Submitted in December 08, 2015.

Accepted for publication in April 04, 2016.

Conflict of interests: none - Sponsoring sources: CAPES.

Correspondence to:

Rua Monte Alegre, 984 - Perdizes

05014-901 São Paulo, SP, Brasil.

E-mail: alessandrafocosi@gmail.com

(C) Sociedade Brasileira para o Estudo da Dor

\section{RESUMO}

JUSTIFICATIVA E OBJETIVOS: $\mathrm{O}$ acesso à Internet cresce progressivamente e ela é considerada a primeira fonte de informação, inclusive sobre saúde. Há um aumento da prevalência de pacientes com dores crônicas e o acesso à assistência especializada ainda é escasso. A web tem a possibilidade de abranger maior número de pessoas, mas ainda há poucos estudos que exploram a relação entre dor e Internet. Assim, o objetivo deste estudo foi caracterizar o universo com o qual os brasileiros se deparam ao pesquisar sobre dor na Internet.

MÉTODOS: Foi utilizada análise documental da primeira página de busca do Google web empregando oito descritores, selecionados considerando pesquisa bibliográfica, ferramenta Google Trends e diferentes modos de expressão da população ("dor"; "dor crônica"; "eu tenho dor"; "eu sinto dor"; "dor de cabeça"; "cefaleia"; "dor nas costas"; e "dor lombar").

RESULTADOS: Obtiveram-se ao final da pesquisa 64 resultados válidos, categorizados em websites e Virtual Settlement. Dentre os websites encontraram-se páginas: de portais de saúde (19); desenvolvidas por especialistas ou sociedades médicas (14); de jornais e revistas online (19); ou de bibliotecas virtuais (2). Na categoria Virtual Settlement: destacam-se blogs (1), fóruns (3), páginas do Facebook (1); vídeos do Youtube (1) e páginas da Wikipédia (4). Também se observou portais que permitem interação entre os usuários e administradores dos sites.

CONCLUSÁO: Estão disponíveis na Internet muitas informaçôes sobre dor, o que alerta para a importância de o profissional de saúde utilizar a Internet como aliada na promoção de saúde de seus pacientes e saber manusear suas desvantagens.

Descritores: Dor crônica, Empoderamento, Internet.

\section{INTRODUCTION}

Information and communication technologies (ICTs) constantly influence daily life of people, especially of those with access to the Internet. It is not possible to ignore the expressive growth in the number of users connected to the network for the most different purposes, because according to data of the Brazilian Institute of Geography and Statistics $(\mathrm{IBGE})^{1}$, in 2011 there has been $143.8 \%$ increase in the number of connected people, as compared to previous data.

Internet is already widely used, both in computers and cell phones, with incredible growth ${ }^{1}$ and is used as research site (e.g., to look for scientific references), research object (being what is being studied), and research tool (data col- 
lection tool) $)^{2}$.

So, the worldwide web is a tool to promote health and, as a consequence, to empower individuals, that is, a partner in their search for better understanding what they feel and sharing knowledge $\mathrm{e}^{3-10}$. Health promotion is the process of qualifying the community in order to reach physical, mental and social wellbeing ${ }^{11}$. This concept was based on the Universal Declaration of Human Rights, proclaimed in 1948, which considers fundamental that all individuals have assured health and wellbeing for them and their families ${ }^{12}$.

Empowerment, according to the European Network on Patient Empowerment (ENOPE) definition, is the process aiming at helping individuals to be in control, which includes helping people to take initiatives, solve problems and get ownership of their own decisions ${ }^{13,14}$.

When chronic pain patients take the initiative of looking for specialized treatment, they not always get adequate assistance and so they end up procrastinating of even not looking for assistance ${ }^{15}$. In these cases, there is also a reinforcement for the use of the Internet, since available information may help their search and support the need to look for health professional assistance ${ }^{8,16}$.

On the other hand, when patients look for therapy and feel that they are not being adequately treated, it is common that issues and insecurities arise with regard to their clinical presentation and, again, the network is the primary access media to mobilize other resources and meet their requirements ${ }^{17}$.

A Brazilian study on the use of the Internet for health-related searches ${ }^{18}$ has shown that $80 \%$ of participants referred that the network is their primary source of information about health and, from them, 90\% look for information about their own health and $79 \%$ about family members health. A similar international study ${ }^{16}$ has observed that for $53 \%$ of participants web information influences decisions about their health, treatment and decision to look or not for medical assistance.

In light of the above, it is understood that the search for Internet content shall continuously grow and it is necessary that the academy get ownership of the cyberspace. So, this study aimed at characterizing the universe faced by the individual when looking for information about pain in the Internet, using the Google search tool.

\section{METHODS}

This study was carried out in 2014 and was designed as from documental analysis, modality very close to literature review, however they differ because this is material still not having received analytical treatment ${ }^{19,20}$.

Google database was used for data collection, since this is the most popular search tool among users worldwide ${ }^{5,21}$.

In the attempt to reproduce painful lay people behavior, eight different keywords were used during Google search, namely: pain; chronic pain; I have pain; I feel pain; head pain; headache; back pain; low back pain.

To select search terms, literature was reviewed considering the higher prevalence of different types of psychophysical pain; highest interest in search topics evaluated by Google Trends tool ${ }^{22}$; and the mode of expression (technical and lay language) to expand evaluation scope.

Descriptors "pain" and "chronic pain" were used for being more generic and for referring both to symptom and diagnosis. Terms "I have pain" and "I feel pain" have been also included in the study to explore other possibilities of expression which are often used by painful people. Other terms were also investigated, such as "I suffer with pain", but were not used in the study because there was a higher number of results not matching our inclusion criteria.

Headache and low back pain were chosen due to the high prevalence of such diagnoses in the general population, and their more popular terms: "head pain" and "back pain" $10,23,24$.

It was necessary to establish some exclusion criteria related to contents written in foreign languages, which did not address pain psychophysical aspect, advertisements, music, poems and paronym, images, pain as symbolism (mourning, emotion or concern) or very specific news (news about a congressman feeling chest pain).

Results obtained in the first pages of each evaluated keyword were explored and the product of the whole search was mapped and classified with regard to its organization in the web (Websites, Virtual Settlement[1]) and the frequency in which they appeared, defining the universe users face when searching about pain in the worldwide web.

With regard to ethical issues involved in the study, there has been no need for Ethics Committee approval or for free and informed consent term, since it was carried out in a public environment and was produced without the intervention of researchers, amenable to observation and analysis $^{25}$.

\section{RESULTS}

All descriptors were entered in the Google web tool, which has returned in average $7,539,500$ results in 0.26 seconds. Considering just the first displayed page, 85 search products were obtained and after applying exclusion criteria, 21 were removed from the study and four results were not considered for being repeated in more than one search term, in a total of 64 valid products.

Results were classified according to their organization in the web: (1) Websites, (2) Virtual Settlement and (3) excluded. Then, each category was subdivided to classify results according to the type of material. So, Websites category was made up of sites related to health, disease and wellbeing; medical society's sites or those developed by pain specialists; online newspapers or journals; and sites related to Virtual Libraries which publish scientific articles and in general are linked to universities or specialty societies. 
Virtual Settlement category, for being based on a series of communications sharing, was made up of blogs; Facebook pages; Youtube videos; Wikipedia articles; and discussion forums coordinated both by lay and specialist users. Excluded results were grouped in a different category.

To help understanding the study, a table was developed to give an overview of the frequency of results obtained in each category by keyword searched in the Google web (Table 1).

Results classified as websites, especially those exclusively related to health are to be highlighted in table 1 (19), followed by online newspapers and journals (19) and medical or health professional societies (14). In a lower number, two scientific articles were found in Virtual Libraries when searching for "chronic pain" and "headache".

With regard to Virtual Settlement category, in general a smaller number of results was found, being that Wikipedia had five pages about "pain", "chronic pain", "head pain", "headache" and "back pain". It is worth highlighting that searches for "head pain" and "headache" have led to the same page.

In the sequence, forums, both coordinated by laymen and specialists, have totaled three results. And Youtube, Facebook and Blogs corresponded to one valid result each.

Major results obtained by searching keywords in Google web are explained below. The first searched term was "pain", for which 13 results were found, but eight were excluded from the search for being: paronyms (5), pain as symbolism, such as mourning (2), and specific news (1). Another three sites belong to medical or specialist societies, however two of them had no specific information related to the search, rather directing users to the home page and forcing them to carry out a new search among several different contents. In addition to these results, we have also found one online newspaper or journal article and one on Wikipedia. It is also worth mentioning that except for Wikipedia, it was not possible to find interaction among users in such sites.

With regard to keyword "chronic pain", 10 results were found, being three published by sites displaying exclusively health-related subjects, three by medical or specialist societies, two by online newspapers or journals, one article found in a virtual library and one Wikipedia informative page. Just one health website had space for interactivity with lay users; however there has been no moderation by content developers.

When searching for "I have pain" we have also obtained 10 results. From these, four were excluded because they were related to arts (song lyrics), two to health, two to electronic newspapers or journals, one Facebook page and one forum coordinated by lay user. In this search, all results had space for comment sharing among users.

Similarly, when searching for "I feel pain", 4 results were excluded for being related to arts, two online newspapers or journals, one health-related website, one blog, one forum coordinated by laymen and one by a pain specialist. Most websites have space for interactivity with users, except for one electronic journal.

With regard to searches related to symptoms or diagnoses, results were divided by terms, being them: technical (headache and low back pain) and lay terms (head pain and back pain), as shown in table 2 .

When grouping results obtained with technical keywords (headache and low back pain), 15 websites had contents exclusively related to health area, considering those developed by health websites, medical or specialist societies and virtual libraries. On the other hand, when searching for lay terms (head pain and back pain) a higher number of results were found in online newspapers and journals (10) and in other tools providing users interference (3).

Table 1. Results obtained with the use of all keywords

\begin{tabular}{|c|c|c|c|c|c|c|c|c|c|c|c|}
\hline $\begin{array}{l}\text { Categories } \\
\text { Keywords }\end{array}$ & $\begin{array}{l}\text { Health } \\
\text { portals }\end{array}$ & \multicolumn{3}{|c|}{ Websites } & Blogs & Face & \multicolumn{2}{|c|}{ Virtual Settlement } & $\begin{array}{l}\text { Lay } \\
\text { forums }\end{array}$ & $\begin{array}{c}\text { Spec } \\
\text { forums }\end{array}$ & Excluded \\
\hline Chronic pain (10) & 3 & 3 & $2^{*}$ & 1 & 0 & 0 & 0 & 1 & 0 & 0 & 0 \\
\hline I have pain (10) & 2 & 0 & 2 & 0 & 0 & $1^{*}$ & 0 & 0 & 1 & 0 & 4 \\
\hline Head pain (11) & 2 & 1 & 7 & 0 & 0 & 0 & 0 & $1^{*}$ & 0 & 0 & 0 \\
\hline Headache (10) & 4 & 3 & 1 & 1 & 0 & 0 & 0 & $1^{*}$ & 0 & 0 & 0 \\
\hline Back pain (10) & $4^{*}$ & 1 & 3 & 0 & 0 & $1^{*}$ & 0 & $1^{*}$ & 0 & 0 & 0 \\
\hline
\end{tabular}

* Refer to results repeated in more than one keyword

MS = medical societies; $\mathrm{N}=$ newspapers; jour = journals; Lib = libraries; Face = Facebook; Wik = Wikipedia; spec = specialists. 
Table 2. Results obtained with keywords "head pain", "headache", "back pain" and "low back pain"

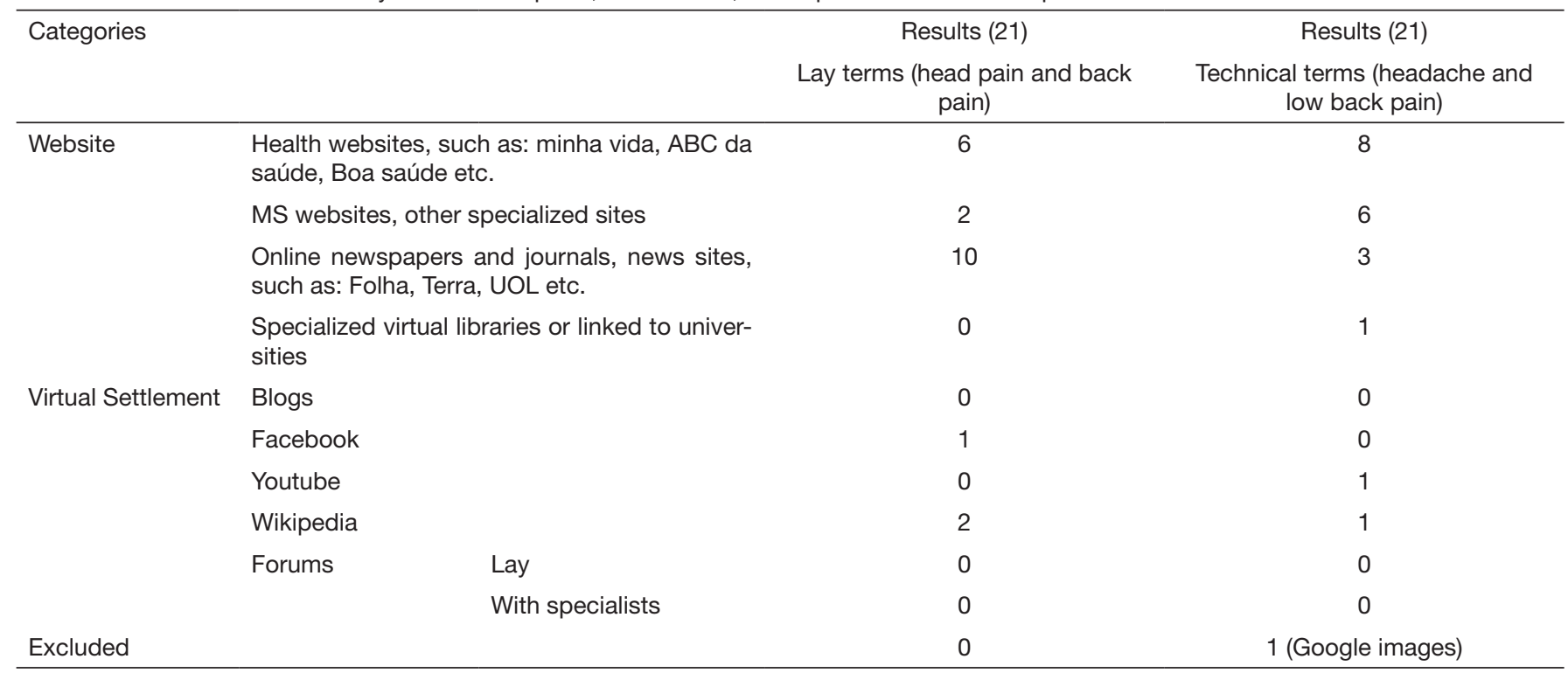

\section{DISCUSSION}

It is common for professionals working with chronic pain patients to complain about patients' passive behavior and the search for magic solutions. However, as seen in the literature, professionals should encourage patients to adopt a more active position with regard to their therapy, making them aware of the disease and of changes in their daily lives, inserting behafiors of self-care, body awareness, practice of physical exercises and, in general, good adhesion to treatment ${ }^{26,27}$.

A way to make individuals more active is to supply information, which is a critical tool for the effectiveness of proposed therapy. So, tools spreading information on health in the Internet have important role in spreading knowledge, because they pave the way for patients' empowerment, since information becomes centered on individuals and not only on health professionals, allowing them to evaluate and make choices with regard to their own therapy ${ }^{28}$.

Studies show that Internet users resort to search tools, such as Google, to search for relevant subjects and usually do not explore different pages of results, preferring to repeat the search if they do not find what they want in the first page $^{10,29}$.

Our results confirm international literature because it was possible to observe that Internet is an important source of information about health, even about pain-related contents, and is a tool being increasingly used by people, being possible to observe in different searched pages a high number of user accesses and interactions ${ }^{3,4,5,7,10,21,30}$.

We decided in this study to use the documental research modality, because this is recommended when researchers aim at capturing information directly from the source, without their intervention. Documental files are a rich source of evidences which may supply elements to help investigators justifying their statements ${ }^{19,20}$.
This modality has made feasible the mapping which has shown that the use of the generic term "pain", as well as of popular expressions "I have pain" and "I feel pain", has produced the highest number of results excluded from the study, that is, these are not terms favoring individuals' empowerment. In the search with keywords indicating medical diagnosis [chronic pain, low back pain and headache] results had better scientific support with lower number of exclusions. However, for diagnostic-related search, there is still a higher number of results produced by qualified professionals, which tends to generate higher quality content and confirms Bailey et al. study findings ${ }^{10}$.

On the other hand, results considered with better scientific support, such as those produced by virtual libraries, are in general aimed at health area professionals with formal language and technical jargon, which makes difficult for general population looking for information about pain/health to understand their meaning. The way of supplying information should also be considered since Brazilian population has social inequalities, in addition to different opportunities to quality education access, factors considered by the World Health Organization $^{31}$ as obstacles for understanding written communication.

Our study could also observe that, in addition to information, users also face results generating interactive content, especially in forums, social media, Youtube, Wikipedia, blogs and other websites opening space for comments. So, it was observed that when there is interaction, there is a new possibility of sharing information, both among users and webmasters; however, this is still a new field and scarcely explored by academic studies.

Finally, it should be stressed that Internet environment is characterized by its "constantly changing and ephemeral nature" 32 , so some results obtained in this study possibly will no longer be available online after some time. 


\section{CONCLUSION}

There is a large number of contents about pain available online and this calls the attention for the need for professionals to increasingly accept that individuals will look for health content in the Internet and instead of criticizing them, it is important to educate patients about how to carry out searches using technical terms and teaching them how to identify quality information. In this sense, it is relevant to consider the advantages and to know how to handle disadvantages of using the web as a tool for empowerment and health promotion.

This mapping made clear the need to deepen and carry out new studies involving health and virtual universes, especially with regard to evaluating the quality of information available in the Internet, the way such information is presented, as well as if it answers to users' demands.

\section{REFERENCES}

1. Instituto Brasileiro de Geografia e Estatística. Pesquisa Nacional por Amostra de Domicílios - Acesso à Internet e Posse de Telefone Móvel Celular para Uso Pessoal. Brasília: IBGE; 2014.

2. Fragoso S, Recuero R, Amaral A. Métodos de pesquisa para internet. Porto Alegre: Sulina; 2011. 239p.

3. Malafaia G, Castro AL, Rodrigues AS. A qualidade das informaçóes sobre doenças disponíveis em websites brasileiros: uma revisăo. Arq Bras Ciênc Saúde. 2011;36(2):72-8.

4. Lorence D, Abraham J. A study of undue pain and surfing: using hierarchical criteria to assess website quality. Health Informatics J. 2008;14(3):155-73.

5. Washington TA, Fanciullo GJ, Sorensen JA, Baird JC. Quality of chronic pain websites. Pain Med. 2008;9(8):994-1000.

6. Souza JF, Marinho CL, Guilam MC. [Medicine consumption and the internet: critical evaluation of a virtual community]. Rev Assoc Med Bras. 2008;54(3):225-31. Portuguese.

7. Corcoran TB, Haigh F, Seabrook A, Schug SA. The quality of internet-sourced information for patients with chronic pain is poor. Clin J Pain. 2009;25(7):617-23.

8. Park JK, Chung HE, Yoo WS. Is the internet a primary Source for consumer information search?: Group comparison for channel choice. J Retailing Consumer Serv. 2009;16(2):92-9.

9. Gondim AP, Weyne DP, Ferreira BS. Qualidade das informaçóes de saúde e medicamentos nos sítios brasileiros. Einstein. 2012;10(3):335-41

10. Bailey SJ, LaChapelle DL, LeFort SM, Gordon A, Hadjistavropoulos T. Evaluation of chronic pain-related information available to consumers on the internet. Pain Med. 2013;14(6): 855-64.
11. Organização Mundial de Saúde. The Ottawa Charter for Health Promotion: first in ternational conference on Health Promotion. Ottawa: WHO; 1986.

12. Organização das Naçōes Unidas. The Universal Declaration of Human Rights. Paris $\mathrm{UN} ; 1948$.

13. European Network on Patient Empowerment (ENOPE). Editorial: patient empowermentwho empowers whom? Lancet. 2012;379(9827):1677.

14. Te Boveldt N, Vernooij-Dassen M, Leppink I, Samwel H, Vissers K, Engels Y. Patient empowerment in cancer pain management: an integrative literature review. Psychooncology, 2014;23(11):1203-11.

15. Hamasaki EIM, Kerbauy RR. Será o comportamento de procrastinar um problema de saúde? Rev Bras Ter Comport Cogn. 2001;3(2):35-40.

16. Fox S, Purcell K. Chronic disease and the Internet. Washington, DC: Pew Internet $\&$ American Life Project; 2010. 67p.

17. Shavers VL, Bakos A, Sheppard VB. Race, ethnicity, and pain among the U.S. adult population. J Health Care Poor Underserved. 2010;21(1):177-220.

18. Moretti FA, Oliveira VE, Silva EM. Access to health information on the internet: a public health issue? Rev Assoc Med Bras. 2012;58(6):650-8. English, Portuguese.

19. Sá JR, Almeida CD, Guindani JF. Pesquisa documental: pistas teóricas e metodológicas. Revista Brasileira de História \& Ciências Sociais. 2009;1(1):1-15.

20. Lüdke M, André MEDA. Pesquisa em educação: abordagens qualitativas. São Paulo: Editora Pedagógica e Universitária; 1986. 99p.

21. Silva LV, Mello Jr JF, Mion O. Avaliação das informaçôes sobre rinite alérgica em sites brasileiros na rede mundial de computadores (Internet). Rev Bras Otorrinolaringol. 2005;71(5):590-7

22. Google Trends [homepage na internet]. [acesso em 29 jun 2013]. Disponível em: https://www.google.com.br/trends/explore\#cmpt=q).

23. Kreling MC, da Cruz DA, Pimenta CA. [Prevalence of chronic pain in adult workers]. Rev Bras Enferm. 2006;59(4):509-13. Portuguese.

24. Queiroz LP, Peres MF, Kowacs F, Piovesan EJ, Ciciarelli MC, Souza JA, et al. Chronic daily headache in Brazil: a nationwide population-based study. Cephalalgia. 2008;28(12):1264-9.

25. Eysenbach G, Till JE. Ethical issues in qualitative research on internet communities. BMJ. 2001;323(7321):1103-5.

26. Loduca A, Samuelian C. Avaliaçâo psicológica: do convívio com dores crônicas à adesão ao tratamento na clínica de dor. In: Alves Neto O, Cost CM, Siqueira JTT, Teixeira MJ, (editores). Dor, princípios e prática. 1ª ed. Porto Alegre, Artmed: 2009. 382-97p.

27. Loduca A, Müller BM, Amaral R, Souza AC, Focosi AS, Samuelian C, et al. Retrato de dores crônicas: percepção da dor através do olhar dos sofredores. Rev Dor. 2014;15(1):30-5.

28. Lefevre F, Lefevre AM, Madeira W. Hipertrofia das mediaçóes, internet e empoderamento, no campo da saúde-doença. Saude Soc. 2007;16(3):149-57.

29. Eysenbach G, Köhler C. How do consumers search for and appraise health information on the world wide web? Qualitative study using focus groups, usability tests, and in-depth interviews. BMJ. 2002;324(7337):573-7.

30. Tirlapur SA, Leiu C, Khan KS. Quality of information on the internet related to bladder pain syndrome: a systematic review of the evidence. Int Urogynecol J. 2013;24(8):1257-62.

31. Organização Mundial de Saúde. Protección y seguridad en internet: retos y avances en los Estados miembros: basado en los resultados de la segunda encuesta mundial sobre cibersalud. Genebra: WHO; 2012.

32. Fragoso S, Recuero R, Amaral A. Métodos de pesquisa para internet. Porto Alegre: Sulina; 2011. 239p. 